\title{
EVALUASI LINGKUNGAN PENGENDALIAN DALAM PERTUMBUHAN USAHA YANG CEPAT: STUDI KASUS PADA PT G
}

\author{
Heny Kurniawati \\ Jurusan Akuntansi, Fakultas Ekonomi dan Bisnis, Bina Nusantara University \\ Jl. K.H. Syahdan No. 9, Palmerah, Jakarta 11480 \\ hkurniawati@binus.edu
}

\begin{abstract}
The effective Internal Control System plays fundamental role in a strong corporate governance. One important component of COSO Internal Control is Control Environment. This case study try to describe and discuss about the strengths and weaknesses of Control Environment, one of the Internal Control componen, of company $G$, a financial institution and how rapid bussiness changes affect the existing control environment. The result of this study showed that rapid business changes and the failure to identify and manage risks of the changes affect the strengths of existing control environment and heighten the weaknesses of control environment.
\end{abstract}

Keywords: audit, internal control, environmental control, risk assessment

\begin{abstract}
ABSTRAK
Suatu sistem pengendalian intern yang efektif merupakan dasar penting dalam tata kelola perusahaan yang baik. Lingkungan pengendalian merupakan salah satu komponen yang paling mendasar dalam Sistem Pengendalian Intern berbasis COSO. Studi kasus ini mendeskripsikan dan membahas mengenai kekuatan dan kelemahan salah satu komponen Sistem Pengendalian Intern yaitu Lingkungan Pengendalian pada PT G, sebuah perusahaan yang bergerak di bidang keuangan, dan bagaimana pertumbuhan usaha yang cepat mempengaruhi kekuatan lingkungan pengendalian yang ada. Studi kasus ini menunjukkan bahwa pertumbuhan usaha yang cepat dan kegagalan perusahaan untuk untuk mengidentifikasi dan mengelola risiko dari perubahan itu berpengaruh terhadap kekuatan lingkungan pengendalian yang telah dibangun oleh perusahaan dan menguatkan kelemahan-kelemahan lingkungan pengendalian perusahaan.
\end{abstract}

Kata kunci: audi , pengendalian intern, lingkungan pengendalian, pengelolaan risiko 


\section{PENDAHULUAN}

Kasus-kasus keuangan seperti Enron, Worldcom, dan Tyco mengingatkan kembali kepada kita mengenai pentingnya sistem pengendalian intern dalam suatu organisasi. Pengendalian intern yang baik memberikan dasar yang kuat dalam tata kelola perusahaan dan merupakan alat untuk membantu perusahaan mencapai tujuannya. Penelitian Doyle, Ge, dan McVay menunjukkan bahwa pengendalian intern merupakan salah satu penggerak kualitas laba, pengendalian intern yang buruk mempengaruhi kualitas laba yang dihasilkan perusahaan. (Doyle, Ge \& McVay, 2007). The Committee of Sponsoring Organizations of the Treadway Commission (COSO, 1992) menyatakan bahwa pengendalian intern merupakan: a process, effected by an entity's board of directors, management and other personnel. This process is designed to provide reasonable assurance regarding the achievement of objectives in effectiveness and efficiency of operations, reliability of financial reporting, and compliance with applicable laws and regulations.

Pengendalian intern yang kuat merupakan alat untuk membantu manajemen mencapai tujuan perusahaan dan mengurangi risiko fraud dengan cara mendeteksi lebih dini (Peterson \& Zikmund, 2004). Dengan pengendalian intern yang efektif, pemangku kepentingan dapat meletakkan kepercayaannya bahwa perusahaan telah dijalankan dengan baik untuk mencapai tujuan perusahaan dan risiko fraud telah dimitigasi semaksimal mungkin.

Pengendalian Intern terdiri dari lima komponen yang saling terkait satu sama lain. Dalam pengendalian intern yang efektif seluruh komponen tersebut harus bekerja dan mempunyai keterkaitan yang baik. Kelima komponen tersebut yaitu lingkungan pengendalian (control environment), pengelolaan risiko (risk assessment), aktivitas pengendalian (control activities), informasi dan komunikasi (information and communication), dan Pengawasan (monitoring) (COSO:1998). Komponen pertama, Lingkungan Pengendalian merupakan tone of the top organisasi yang mampu mempengaruhi kesadaran manusia-manusia di dalamnya. Komponen kedua, Pengelolaan Risiko merupakan proses identifikasi, analisa, dan pengelolaan risiko entitas yang menghambat entitas untuk mencapai tujuannya. Komponen ketiga, aktivitas Pengendalian, merupakan kebijakan dan prosedur yang membantu memastikan bahwa arahan manajemen diikuti oleh entitas. Komponen keempat, Informasi dan Komunikasi, yaitu proses identifikasi, pemerolehan, dan pertukaran informasi dalam bentuk dan kerangka waktu yang memungkinkan individu untuk melaksanakan tanggung jawabnya. Komponen terakhir, Pengawasan, yaitu proses yang menilai kualitas kinerja pengendalian intern dari waktu ke waktu.

Lingkungan Pengendalian merupakan dasar bagi komponen lainnya. Komponen ini terkait dengan bagaimana manajemen puncak mendesain dan membudayakan prinsip kejujuran dan etika dalam organisasi, menetapkan dan menegakkan pengendalian untuk mencegah dan mendeteksi kesalahan dan fraud yang terjadi dalam organisasi. Hasil penelitian Lawrence, Meza, dan Vyas menunjukkan bahwa terdapat hubungan yang signifikan antara pengendalian intern atas pelaporan keuangan dan pengendalian intern atas aktivitas operasi. Selain itu, penelitian tersebut juga menekankan akan arti pentingnya lingkungan pengendalian yang efektif, karena tone of the top memiliki efek luas dalam pengendalian intern organisasi secara keseluruhan (Lawrence, Meza \& Vyes, 2010). Unsur-unsur dalam lingkungan pengendalian meliputi integritas dan nilai etika, komitmen terhadap kompetensi, filosofi manajemen dan gaya operasi, struktur organisasi, pendelegasian tugas dan wewenang, Board of Directors dan Komite Audit, Kebijakan dan praktik sumber daya manusia, dan Kegiatan Pengawasan.

Dalam studi kasus ini, akan dideskripsikan dan dibahas mengenai kekuatan dan kelemahan salah satu komponen Sistem Pengendalian Intern yaitu Lingkungan Pengendalian pada PT G, sebuah perusahaan yang bergerak di bidang keuangan, dan bagaimana pertumbuhan usaha yang cepat mempengaruhi kekuatan lingkungan pengendalian yang ada. Studi kasus ini menunjukkan bahwa 
pertumbuhan usaha yang cepat dan kegagalan perusahaan untuk untuk mengidentifikasi dan mengelola risiko dari perubahan itu berpengaruh terhadap kekuatan lingkungan pengendalian yang telah dibangun oleh perusahaan dan menguatkan kelemahan-kelemahan lingkungan pengendalian perusahaan.

PT G merupakan perusahaan yang bergerak di bidang keuangan dengan memberikan pinjaman kepada masyarakat dalam jangka waktu tertentu. Target pasarnya adalah masyarakat golongan menengah ke bawah yang memerlukan dana murah dalam jangka waktu cepat dengan prosedur kredit yang mudah dan sederhana.Pada tahun 2009, kredit yang disalurkan oleh Perusahaan G telah mencapai Rp59,5 triliun dengan nasabah 19,8 juta. Selama ini PT G adalah perusahaan yang menguasai pasar bisnis pemberian pinjaman mudah dan cepat, namun dengan regulasi Pemerintah baru yang mempermudah pesaing-pesaingnya untuk memasuki bisnis ini membuat persaingan yang mengancam penguasaan pasar oleh PT G. Menghadapi hal tersebut, PT G mempersiapkan diri untuk tetap menjadi perusahaan dengan market share terbesar dalam bisnis keuangan. Manajemen berpikir bahwa menguasai pasar adalah kunci keberhasilan menjadi pemimpin dalam bisnis. Untuk menguasai pasar, PT G berusaha untuk memposisikan dirinya sedekat mungkin dengan pelanggan. Hal ini dilakukan dengan cara membuka cabang dan unit sebanyak mungkin dan sedekat mungkin dengan masyarakat. Dalam waktu yang singkat PT G telah membuka kantor cabang dan pembantu sebanyak 4.800 buah. Kantor Wilayah dan Kantor Cabang diberikan target untuk membuka kantor cabang baru sebanyak-banyaknya untuk mempercepat pemekaran bisnis. Selain itu, PT G juga terus berinovasi dengan produk-produk layanan baru kepada konsumen.

\section{METODE PENELITIAN}

Penelitian dilakukan dengan metode kualitatif eksploratoria. Pengumpulan data dan informasi dilakukan melalui studi pustaka dan literature, review dokumen, dan wawancara dengan sumber informasi.

\section{HASIL DAN PEMBAHASAN}

\section{Integritas dan Nilai etika}

Perusahaan mempunyai filosofi budaya kerja yang selalu disosialisasikan kepada seluruh pegawai sehingga hampir seluruh pegawai mengetahui dan memahami filosofi budaya kerja perusahaan. Pada beberapa sudut ruangan kantor pusat maupun cabang dipasang filosofi tersebut pada dinding yang mudah untuk dilihat untuk selalu mengingatkan pegawai akan filosofi tersebut. Filosofi tersebut adalah karakter ideal yang diharapkan dapat dimiliki oleh seluruh pegawai perusahaan. Selain itu, perusahaan juga mempunyai buku kode etik dan peraturan disiplin pegawai yang memuat hal-hal yang harus dilakukan dan hal-hal yang tidak boleh dilakukan dan sanksi beserta prosedur pengenaannya bagi pegawai yang melanggar. Jika terdapat pelanggaran oleh pegawai, satuan pengawasan intern akan memeriksa pegawai yang bersangkutan sekaligus mengumpulkan bukti yang relevan terkait kasus tersebut dan melaporkan hasil investigasinya kepada pejabat yang berwenang untuk memutuskan sanksi atas kasus tersebut. Aturan-aturan dan kode etik pegawai tersebut menekankan pada fraud yang terkait dengan misappropriation of assets, yang pada umumnya ditemui pada pegawai. Sedangkan aturan dan kode etik yang menekankan pada fraud terkait kemungkinan salah saji pelaporan keuangan, yang umumnya dilakukan oleh manajemen tingkat atas belum diatur secara jelas. PT G belum memberikan perhatian yang khusus mengenai pentingnya pelaporan keuangan yang kompeten dan dapat diandalkan. 
Tuntutan untuk menguasai pasar dengan membuka kantor sebanyak-banyaknya dari manajemen tingkat atas yang diturunkan kepada manajemen tingkat di bawahnya dikaitkan dengan penilaian kinerja dan insentif pegawai. Hal itu mememaksa manajemen menengah dan bawah untuk melakukan segala daya upaya untuk memenuhi penilaian kinerja. Target pembukaan kantor cabang kurang disesuaikan dengan load pekerjaan rutin pada kantor cabang pembuka dan jumlah sumber daya manusia yang ada menyebabkan target tersebut tidak realistis untuk dicapai dan menimbulkan tekanan yang tinggi pada pegawai.

Komitmen manajemen yang sangat kuat terhadap pertumbuhan usaha agar dapat dilaksanakan dengan cepat dipahami oleh pegawai. Namun komitmen tersebut menjadi kelemahan ketika manajemen menengah dan bawah yang ada di lapangan menemui kesulitan dan hambatan dalam pembukaan kantor cabang baru atau kegagalan mencapai target. Para manajer lapangan kurang dapat mengkomunikasikan hambatan dan kesulitan di lapangan kepada manajer di atasnya karena akan berpengaruh terhadap penilaian kinerja mereka. Hal ini mengakibatkan manajemen tingkat atas tidak memperoleh informasi yang lengkap dalam pengambilan keputusan mereka.

Dari uraian di atas, dapat diketahui bahwa kekuatan PT G pada unsur integritas dan nilai etika terlihat pada adanya budaya kerja, aturan dan kode etik telah yang telah diformalkan, dikomunikasikan dan disosialisasikan kepada seluruh pegawai. Selain itu, aturan-aturan tersebut terutama yang terkait dengan pelanggaran dan sanksi dipahami oleh pegawai. Perubahan berupa pertumbuhan usaha yang cepat pada PT G berpengaruh terhadap integritas dan nilai etika yang dibangun oleh PT G.

Sedangkan kelemahan penegakan integritas dan nilai etika PT G terutama yang dipengaruhi kondisi perusahaan yang sedang mengalami pertumbuhan usaha yang pesat antara lain belum adanya aturan formal mengenai pelanggaran terkait dengan pelaporan keuangan; penilaian kinerja dan insentif terhadap target yang sulit dicapai memberikan tekanan pada pegawai untuk pencapaian hasil jangka pendek saja; dan komunikasi antara manajer atas dan manajer lapangan kurang lancar terkait dengan hambatan dan kegagalan pertumbuhan usaha yang berpotensi mengganggu ketepatan pengambilan keputusan.

Kelemahan-kelemahan pengendalian intern tersebut dapat mengakibatkan risiko pelaporan dan informasi yang tidak reliable dan pengambilan keputusan yang tidak tepat. Dalam pengendalian intern yang baik, manajemen atas sebaiknya membangun prinsip dan budaya kejujuran dan etika dalam organisasi dengan menetapkan target dan penilaian kinerja yang realistis, memberikan respon yang tepat atas hambatan dan kegagalan, dan menerapkan aturan yang jelas mengenai pentingnya pelaporan yang dapat diandalkan.

\section{Komitmen terhadap Kompetensi}

PT G telah mempunyai kebijakan sumber daya manusia yang mengatur tentang prosedur perekrutan pegawai, pelatihan pegawai, promosi, mutasi, dan pemberhentian. Selain itu, PT G juga telah mempunyai uraian tugas dan tanggung jawab serta syarat kompetensi masing-masing jabatan. Namun, dalam periode pertumbuhan usaha yang cepat, aturan dan prosedur yang ada menjadi longgar karena kondisi kebutuhan sumber daya manusia dengan jumlah yang banyak dalam waktu yang singkat. Hal ini dapat dilihat dari proses perekrutan pegawai, pelatihan pegawai, dan promosi serta mutasi pegawai.

Pertama, dalam hal perekrutan pegawai. Kantor cabang baru yang dibuka membutuhkan sumber daya manusia. Kebutuhan akan sumber daya manusia pada kantor cabang baru dipenuhi melalui mutasi pegawai kantor cabang yang sudah ada dan perekrutan pegawai baru. PT G telah merencanakan perekrutan pegawai secara periodik untuk memenuhi kebutuhan pegawai tersebut, namun kecepatan pembukaan kantor cabang baru tidak sejalan dengan kecepatan perekrutan pegawai. Untuk memenuhi kebutuhan sumber daya kriteria perekrutan diperlonggar, yaitu dengan menurunkan 
kemampuan akademis, kesesuaian karakter peserta dengan pegawai yang akan dihadapi, dan kesesuaian nilai-nilai calon pegawai dengan budaya dan nilai-nilai perusahaan. Hal ini tidak sejalan dengan komitment manajemen terhadap kompetensi.

Kedua, terkait dengan pelatihan pegawai. PT G mempunyai ketentuan bahwa setiap pegawai baru harus menjalani pelatihan selama periode waktu tertentu dan harus dinyatakan lulus pelatihan serta menjalani magang sebelum terjun ke lapangan. Hal ini sangat diperlukan karena pegawai harus menguasai keahlian tertentu sebelum bisa bekerja pada operasional kantor cabang. Pembukaan kantor cabang baru yang membutuhkan banyak pegawai memaksa manajemen untuk mengurangi waktu pelatihan dan masa magang pegawai baru agar bisa segera ditempatkan pada kantor cabang baru. Beberapa kantor cabang baru, bahkan terisi oleh pegawai baru saja tanpa ada pegawai lama. Hal ini sangat berisiko karena bisnis PT G membutuhkan keahlian, pengalaman, dan integritas pegawai yang teruji.

Ketiga, dalam hal promosi karyawan. Untuk menduduki posisi/jabatan tertentu, PT G telah mempunyai pedoman yang berisi persyaratan, pelatihan, keahlian, dan pengalaman tertentu yang harus dimiliki. Pembukaan kantor cabang baru dan perluasan produk dan usaha membutuhkan pegawai yang harus dipindahkan (mutasi) dan dipromosikan. Kebutuhan yang mendesak membuat manajemen menerapkan persyaratan yang longgar dalam mutasi dan promosi pegawai. Hal ini berisiko pegawai tidak dapat melakukan tugas dan tanggung jawabnya sesuai yang diharapkan perusahaan karena kurang keahlian, pelatihan, atau pengalaman. Risiko kesalahan penanganan suatu transaksi atau aktivitas operasional dan pelaporan yang dapat mengakibatkan kerugian perusahaan dan kurang andalnya pelaporan akan menjadi tinggi dengan ditempatkannya pegawai yang tidak sesuai kompetensinya.

Dari uraian di atas, terlihat bahwa pertumbuhan usaha yang cepat memperlemah lingkungan pengendalian terkait komitmen terhadap kompetensi yang sudah dimiliki oleh perusahaan. PT G menjadi longgar dalam komitmentnya terhadap perekrutan, pelatihan, dan promosi pegawai yang dapat meningkatkan risiko fraud dan salah saji pelaporan keuangan.

\section{Filosofi Manajemen dan Gaya Operasi}

Tantangan industri untuk membuka persaingan dijawab oleh manajemen PT G dengan pengembangan pasar secara besar-besaran dan cepat. Manajemen cepat tanggap dan berani mengambil risiko untuk tercapainya tujuan perusahaan. Namun dalam pengembangan usaha, manajemen belum mengkaji secara mendalam dengan memperhatikan risiko-risiko yang mungkin timbul dan mempersiapkan diri bagaimana mengelola risiko yang mungkin timbul tersebut. Berdasarkan pengamatan dan wawancara diketahui bahwa manajemen mengatasi masalah yang terjadi pada saat masalah tersebut. Kelemahan tersebut tersebut dapat terlihat dari beberapa hal misalnya beberapa kantor cabang yang dibuka tidak mempunyai pasar yang jelas atau dibuka pada lokasi yang rawan perampokan dan pencurian, dan rentang kendali yang semakin luas belum diimbangi dengan sistem pengawasannya.

Manajemen PT G menjalankan operasi perusahaan dan mengkoordinasikan seluruh jajarannya melalui rapat-rapat koordinasi untuk memberikan arahan dan laporan-laporan secara tertulis untuk mendapatkan umpan balik dan pengendalian. Berdasarkan wawancara terhadap beberapa sumber informasi, pegawai dan manajemen menengah dan bawah tidak memberikan usulan atau informasi jika tidak diminta. Laporan secara tertulis merupakan cara komunikasi yang lebih sering digunakan. PT G belum mempunyai prosedur dan pedoman bagaimana menangani whistle blower.

Manajemen PT G belum menyadari pentingnya pelaporan yang andal sebagai dasar pengambilan keputusan. Terdapat beberapa kelemahan dalam informasi akuntansi dan informasi operasi yang berisiko dihasilkannya laporan yang tidak andal. Beberapa informasi dan data harus 
direkonsiliasi secara manual yang berisiko salah saji karena human error. Selain itu, manajemen belum mendorong dihasilkannya laporan keuangan yang tepat waktu dan akurat. Dengan pengembangan usaha yang cepat, proses pelaporan menjadi semakin tertunda karena semakin banyak proses manual dan rekonsiliasi yang harus dilakukan yang memerlukan banyak waktu dan tenaga.

Dari uraian di atas dapat disimpulkan bahwa manajemen PT G adalah tipe manajemen risk taker dan mengandalkan laporan formal sebagai dasar pengambilan keputusannya di satu sisi, namun di sisi lain pelaporan baik keuangan maupun operasional belum dapat diandalkan. Hal ini merupakan suatu kelemahan pengendalian intern, terlebih lagi dalam kondisi pengembangan usaha yang cepat. Dengan kurang perhatiannya manajemen terhadap sistem pelaporan keuangan yang andal menggambarkan bahwa manajemen belum memandang pelaporan sebagai alat kendali untuk menguji pengendalian atas berbagai aktivitas entitas.

\section{Struktur Organisasi}

Unsur struktur organisasi dalam komponen lingkungan pengendalian merupakan suatu kerangka yang di dalamnya kegiatan operasional perusahaan dikelola untuk mencapai tujuan perusahaan. PT G mempunyai struktur organisasi yang terdesentralisasi. Kegiatan utama perusahaan dilakukan pada kantor cabang. Kantor pusat bertugas mengkoordinasikan seluruh aktivitas perusahaan.

Pada saat periode pengembangan usaha, PT G membuka kantor-kantor cabang baru dan kantor cabang pembantu yang pengelolaan dan pengawasannya berada di bawah kantor cabang pembuka. Kantor cabang pembuka, selain melaksanakan aktivitas rutinnya juga bertanggung jawab merencanakan pembukaan kantor cabang pembantu baru, dan mengawasi kantor cabang pembantu yang telah dibuka. Beban pekerjaan dan tanggung jawab bertambah dengan rentang kendali yang lebih luas. Pertama, beban kerja pengawasan bagi para manajer bertambah dengan setiap dibukanya kantor cabang baru. PT G telah mempunyai prosedur pengawasan dan laporan pengawasaannya yang harus dijalani oleh masing-masing manajer. Namun, beban kerja yang bertambah dan tidak sesuai dengan waktu dan kemampuan membuat manajer dan supervisor tidak dapat melaksanakan fungsi pengelolaan dan pengendalian yang optimal. Pemenuhan kinerja hanya sekedar untuk pemenuhan indikator kinerja saja. Selain itu, dikarenakan belum tersedianya sumber daya manusia untuk mengisi posisi-posisi baru pada kantor cabang baru, banyak posisi manajer dan supervisor yang kosong sehingga harus dirangkap dan ditangani oleh seorang manajer atau supervisor. Perangkapan tugas ini menjadikan beberapa tugas pokok rutin menjadi terbengkelai. Pelayanan kepada pelanggan juga terhambat dan lebih memakan waktu. Manajer atau supervisor yang tidak mempunyai waktu yang cukup mendelegasikan sebagian pekerjaan yang menjadi tugasnya kepada bawahannya yang kemungkinan belum mempunyai kemampuan dan pengalaman untuk melaksanakan tugas tersebut.

Kondisi di atas menunjukkan bahwa pertumbuhan usaha yang cepat sangat mempengaruhi kemampuan struktur organisasi dan kemampuan para manajer PT G untuk menjalankan tugas-tugas mereka dan mengawasi aktivitas perusahaan untuk mencapai tujuan perusahaan. Kelemahan pengendalian intern pada struktur organisasi tersebut dapat mengakibatkan timbulnya risiko kesalahan pelaporan baik keuangan dan non keuangan. Salah saji pelaporan tersebut dapat terjadi karena ketidaksengajaan yaitu kesalahan karena ketidaktahuan. Hal ini dimungkinkan dengan adanya pendelegasian tugas kepada orang yang belum cukup kompetensinya atau kesalahan manusia akibat ketidaktelitian dan kurang seksama menjalankan tugas karena kelelahan demi mengejar target penyelesaian banyak pekerjaan dengan waktu yang sangat terbatas.

\section{Pendelegasian Tugas dan Wewenang}

Pertumbuhan usaha yang cepat dengan dibukanya kantor-kantor cabang baru tidak terkejar dengan penyediaan sumber daya memperlemah pengendalian dalam pemisahan tugas dan wewenang. Pada beberapa kantor cabang baru seorang manajer terpaksa merangkap dua aktivitas yang seharusnya 
dipisahkan bahkan beberapa manajer harus merangkap tiga aktivitas kunci yaitu aktivitas otorisasi, penyimpanan, dan pencatatan yang seharusnya dipisahkan. Hal ini merupakan kelemahan pengendalian yang signifikan dalam struktur organisasi yang dapat berakibat terjadinya fraud berupa penggelapan aktiva perusahaan atau salah saji laporan keuangan.

\section{Kebijakan dan Praktek Sumber Daya Manusia}

PT G telah mempunyai prosedur dan kebijakan tertulis dalam perekrutan, pelatihan, promosi, dan renumerasi pegawai. Prosedur tersebut dituangkan dalam surat keputusan direksi. Dalam perekrutan pegawai, biasanya latar belakang pegawai tidak dicek secara mendalam, misalnya dengan menghubungi perusahaan sebelumnya tempat calon pegawai bekerja. PT G bersandar pada Surat Keterangan Berkelakuan Baik dari Kepolisian. Dengan dokumen tersebut, PT G yakin bahwa calon pegawai tidak mempunyai catatan kriminal. Setelah calon pegawai lulus test dan persyaratan pegawai, mereka memperoleh pembekalan atau induksi mengenai pengenalan perusahaan, bagaimana misi dan visi perusahaan, budaya kerja, dan peraturan disiplin pegawai.

Secara berkala, PT G menyelenggarakan pelatihan untuk pegawai baik dalam rangka meningkatkan kompetensi pegawai maupun menyegarkan kembali pengetahuan dan keahlian pegawai. Namun, pelatihan belum merata ke seluruh pegawai, beberapa pegawai mendapatkan porsi pelatihan cukup banyak, sedangkan pegawai yang lain sedikit. Selain itu, pelatihan belum disesuaikan dengan kebutuhan pegawai yang dapat menunjang kemampuan dan keahlian pegawai dalam melaksanakan tugas sehari-harinya.

Renumerasi pegawai PT G didasarkan pada modifikasi antara gaji pokok (base salary) dan evaluasi penilaian kinerja masing-masing unit. Penilaian kinerja unit adalah ukuran mengenai ketercapaian target-target keuangan dan non keuangan yang telah dituangkan dalam rencana kerja dan anggaran perusahaan. PT G belum mempunyai evaluasi penilaian kinerja perorangan sehingga nilai etika dan integritas belum manjadi kriteria dalam penilaian kinerja pegawai.

Karena PT G belum mempunyai sistem penilaian kinerja pegawai secara perorangan, promosi belum didasarkan pada penilaian kinerja dan pedoman etik pegawai. Pegawai boleh mengajukan diri promosi setelah memenuhi kriteria tertentu yang dipersyaratkan dalam suatu jabatan yang meliputi pengalaman, keahlian, dan pelatihan tertentu. Pegawai yang mengajukan promosi tersebut diproses oleh bagian kepegawaian dan diputuskan untuk memperoleh promosi oleh Direksi.

Pada periode pertumbuhan usaha yang cepat, kekurangan dalam kebijakan dan praktek sumber daya manusia menjadi kelemahan yang signifikan. Pertama, dalam hal perekrutan pegawai, untuk memenuhi kebutuhan pegawai yang cukup banyak untuk menempati kantor-kantor cabang baru, PT G memerlukan perekrutan pegawai yang cepat. Untuk memenuhi kebutuhan sumber daya kriteria perekrutan diperlonggar, yaitu dengan menurunkan kemampuan akademis, kesesuaian karakter peserta dengan pegawai yang akan dihadapi, dan kesesuaian nilai-nilai calon pegawai dengan budaya dan nilai-nilai perusahaan. Kedua, terkait dengan pelatihan pegawai. Dengan pegawai yang semakin banyak sedangkan pelatihan belum merata dan sesuai dengan kebutuhan pegawai, bisa menimbulkan aktivitas atau transaksi yang sama diperlakukan secara berbeda yang pada akhirnya akan menimbulkan kerugian perusahaan. Ketiga, dalam hal promosi karyawan. Belum adanya penilaian kinerja perorangan dan belum dikaitkannya nilai-nilai integritas dan etika dalam proses promosi akan menyulitkan keputusan untuk mempromosikan pegawai yang tepat pada posisi yang tepat. Sedangkan penempatan orang yang tepat pada posisi yang tepat merupakan kunci keberhasilan aktivitas perusahaan. 


\section{Board of Directors dan Komite Audit}

Board of Directors PT G terdiri dari pemegang saham dan pihak independen. Anggota Board of Directors mempunyai keahlian dan pengetahuan yang memadai dalam industri PT G. Beberapa diantara anggota Board of Directors memiliki pengetahuan yang cukup bidang akuntansi dan pelaporan keuangan. Board of directors bertemu secara rutin dengan manajemen untuk membahas masalah-masalah yang terkait dengan perusahaan. Selain itu, PT G juga memiliki Komite Audit yang dipimpin oleh salah seorang anggota Board of Directors. Komite Audit terdiri dari anggota yang independen terhadap manajemen dan mempunyai pengetahuan yang memadai terkait keuangan maupun non keuangan pada industri PT G. Uraian tugas dan tanggung jawab Komite Audit telah dituangkan dalam Piagam Komite Audit antara lain Corporate Governance, Pelaporan Keuangan, dan Pengendalian Intern. Komite Audit mempunyai akses langsung kepada Head of Internal Auditor sehingga dapat secara langsung memperoleh informasi mengenai hasil audit Internal Auditor dan pertemuan dilakukan secara periodik.

Dalam masa pengembangan usaha, Board of Directors menaruh perhatian yang cukup besar. Namun, kendala yang dihadapi Board of Directors tidak dapat memperoleh pelaporan keuangan dan non keuangan yang tepat waktu dan dapat diandalkan. Hal ini terkait dengan sikap manajemen yang belum memandang pelaporan keuangan sebagai alat yang dapat membantu pengendalian berbagai aktivitas perusahaan. Hal tersebut mengakibatkan Board of Directors, walaupun telah memenuhi syarat kompetensi, independensi, dan profesionalitas, tidak dapat memberikan pertimbangan dan saran yang tepat dan akurat kepada Manajemen.

\section{Kegiatan Pengawasan}

PT G telah memiliki Komite Audit dan Unit Audit Intern. Pendirian, tujuan, tugas dan tanggung jawab Komite Audit dan Unit Audit Intern tertuang secara formal dalam Comitte Audit Charter dan Internal Audit Charter. Di dalam Internal Audit Charter disebutkan bahwa Unit Audit Intern dipimpin oleh seorang Head of Internal Audit yang bertanggung jawab langsung kepada Direktur Utama. Sedangkan fungsi Internal Audit adalah untuk menyediakan informasi, analisis, perkiraan, rekomendasi, dan konsultasi kepada manajemen. Unit Audit Intern memiliki kewenangan untuk melakukan akses terhadap catatan, karyawan, sumber daya, dan dana serta aset organisasi lainnya yang berkaitan dengan pelaksanaan pemeriksaan. Dalam pelaksanaan tugasnya, Unit Audit Intern PT G telah memiliki kebijakan dan prosedur audit sebagai pedoman dalam melaksanakan tugasnya.

Tugas Unit Audit Intern dilaksanakan secara desentralisasi pada masing-masing wilayah dikepalai oleh Region Head of Internal Audit. Setiap wilayah merencanakan audit termasuk menetapkan ruang lingkup audit dan waktu pelaksanaan audit pada periode yang akan datang dan menyampaikannya kepada Head of Internal Audit, yang kemudian mengkoordinasi dan memastikan ulang rencana audit masing-masing wilayah tersebut, dan menyampaikannya kepada Direktur Utama untuk disetujui. Untuk unit-unit yang hanya berada di kantor pusat, Head of Internal Audit akan meminta beberapa orang auditor dari beberapa wilayah untuk melaksanakan audit unit kantor pusat sesuai dengan rencana yang telah ditentukan. Laporan audit untuk masing-masing wilayah dan unit kerja disampaikan ke Head of Internal Audit, untuk temuan audit yang dapat diselesaikan dan ditindaklanjuti oleh wilayah, Unit Audit Intern kantor pusat hanya mendokumentasikan laporan audit beserta tindak lanjutnya saja. Sedangkan temuan audit yang terkait dengan fraud atau yang tidak dapat diselesaikan oleh kantor wilayah akan dilaporkan oleh Head of Internal Audit dengan manajemen maupun dengan Komite Audit untuk ditindaklanjuti. Komite Audit kemudian menyampaikan temuantemuan audit yang penting kepada Board of Directors. 
PT G telah mempunyai kriteria dan syarat-syarat dalam mengangkat pegawai menjadi bagian dari Unit Audit Intern. Namun, walaupun mempunyai sistem desentralisasi, Unit Audit Intern belum memiliki program Quality Assurance untuk menjamin pelaksanaan fungsi unit internal audit sesuai dengan standar dan kode etik internal auditor. Hal ini memungkinkan adanya perbedaan kualitas audit antara satu wilayah dengan wilayah lain atau tidak terdeteksinya kelemahan terkait aktivitas operasi, pelaporan keuangan, dan pengendalian intern pada suatu wilayah. Selain itu, kegiatan dan fungsi Unit Audit Intern belum pernah direviu oleh pihak eksternal organisasi sebagai evaluasi yang akan disampaikan pada Manajemen dan Board of Directors.

Unit Audit Intern pada PT G telah melaksanakan aktivitas audit pada perusahaan terkait kepatuhan terhadap prosedur dan aturan-aturan yang berlaku pada kantor cabang dan kantor wilayah. Namun, Unit Audit Intern belum melakukan aktivitas audit mendalam terkait dengan sistem dan pelaporan keuangan maupun non keuangan perusahaan dan evaluasi sistem pengendalian intern secara keseluruhan. Unit Audit Intern juga belum berperan dalam mereviu konsep kebijakan atau sistem dan prosedur yang disusun manajemen sebelum disahkan oleh Direksi. Hal ini dikarenakan Unit Audit Intern belum mempunyai sumber daya yang cukup kompeten dan pelatihan berkelanjutan yang cukup untuk auditornya agar dapat melaksanakan kedua aktivitas tersebut. Selain itu, rencana audit dan pelaksanaan audit cukup ketat sehingga seringkali auditor intern tidak mempunyai cukup waktu untuk menjalani pelatihan yang penting dalam melaksanakan tugasnya.

Pada periode pertumbuhan usaha yang cepat, tugas Unit Audit Intern semakin berat. Hal ini dikarenakan kantor cabang yang bertambah dengan cepat, sedangkan untuk setiap kantor cabang harus dilakukan audit minimal dalam periode tertentu. Penambahan personel dalam Unit Audit Intern belum signifikan karena manajemen mengutamakan personel untuk aktivitas operasi terlebih dahulu. Hal ini menyebabkan banyak rencana audit yang tidak dapat dilaksanakan karena keterbatasan waktu. Ditambah lagi, jika terdapat kasus-kasus terkait fraud yang harus cepat diaudit dan diverifikasi oleh Unit Internal Audit.

Pertumbuhan usaha yang cepat semakin menegaskan kelemahan-kelemahan pengendalian intern terkait dengan kegiatan pengawasan. Pertama, terkait masalah ketersediaan sumber daya manusia yang cukup untuk melaksanakan tugas audit yang semakin banyak terutama dari segi kuantitas (banyaknya kantor cabang). Kedua, semakin banyaknya beban kerja auditor memungkinkan kekurangseksamaan dalam melaksanakan prosedur audit yang dapat berisiko audit failure misalnya tidak terdeteksinya fraud baik penggelapan aset atau salah saji dalam pelaporan sedini mungkin, sedangkan PT G belum mempunyai quality assurance untuk memastikan standar kualitas audit yang dilaksanakan pada masing-masing wilayah. Selain itu, tindak lanjut hasil audit tidak dapat secara tepat waktu dilaksanakan oleh unit terkait sedangkan Unit Audit Intern sendiri kewalahan untuk memonitor tindak lanjut hasil audit tersebut. Ketiga,Unit Audit Intern belum dapat melaksanakan tugas lainnya dalam mengevaluasi sistem pengendalian intern secara keseluruhan dan memastikan sistem pelaporan dapat diandalkan. Kelemahan dalam kegiatan pengawasan yang terjadi karena belum adanya sistem yang pengawasan yang memadai dan pertumbuhan usaha yang cepat, dapat berisiko terhadap keandalan pelaporan, kepatuhan terhadap peraturan dan prosedur yang berlaku dan efektivitas dan efisiensi operasi.

\section{PENUTUP}

Studi kasus ini menunjukkan bahwa pertumbuhan usaha yang cepat dan kegagalan perusahaan untuk untuk mengidentifikasi dan mengelola risiko dari perubahan itu berpengaruh terhadap kekuatan lingkungan pengendalian yang telah dibangun oleh perusahaan dan menguatkan kelemahankelemahan lingkungan pengendalian perusahaan. Kelemahan terkait penegakan integritas dan etika yang ditunjukkan dengan belum adanya aturan formal mengenai pelanggaran terkait pelaporan keuangan; penilaian kinerja dan insentif terhadap target yang tidak realistik; dan komunikasi kurang 
lancar akan semakin lemah dengan kondisi kantor cabang yang lebih banyak dan rentang kendali yang lebih lebar. Komitmen terhadap kompetensi yang sudah dimiliki oleh perusahaan, dengan pertumbuhan usaha yang cepat menjadi menjadi lemah dalam hal perekrutan, pelatihan, dan promosi pegawai yang dapat meningkatkan risiko fraud dan salah saji pelaporan keuangan. Manajemen merupakan tipe manajemen risk taker dan mengandalkan laporan formal namun belum menyadari pentingnya informasi akuntansi sebagai alat pengendali operasi perusahaan. Hal ini merupakan suatu kelemahan pengendalian intern, terlebih lagi dalam kondisi pengembangan usaha yang cepat. Pertumbuhan usaha yang cepat sangat mempengaruhi kemampuan struktur organisasi dan kemampuan para manajer PT G untuk menjalankan tugas-tugas rutin mereka dan mengawasi aktivitas perusahaan untuk mencapai tujuan perusahaan. Pertumbuhan usaha yang cepat memperlemah pengendalian terkait pendelegasian tugas dan wewenang pada aktivitas kunci yang seharusnya dipisahkan. Belum adanya penilaian kinerja perorangan dan belum dikaitkannya nilai-nilai integritas dan etika dalam proses promosi akan menyulitkan keputusan untuk mempromosikan pegawai yang tepat pada posisi yang tepat. Board of Directors, walaupun telah memenuhi syarat kompetensi, independensi, dan profesionalitas, tidak dapat memberikan pertimbangan dan saran yang tepat dan akurat kepada Manajemen karena tidak diperolehnya informasi yang tepat waktu dan akurat. Mempertimbangkan pentingnya lingkungan pengendalian dalam suatu sistem pengendalian yang efektif, dan bagaimana peningkatan risiko fraud dan salah saji pelaporan akibat pertumbuhan usaha yang cepat, seharusnya mengidentifikasi dan mengelola risiko dalam mengembangkan bisnisnya dan mengantisipasinya terutama yang terkait dengan sistem pengendalian intern.

\section{DAFTAR PUSTAKA}

COSO Internal Control. (1992). Integrated Framework. Diunduh pada 28 Februari 2011, dari http://www.snai.edu/cn/service/library/book/0-Framework-final.pdf

Doyle, J., Ge, W., \& McVay, S. (2007). Determinants of weaknesses in internal control over financial reporting. Journal of Accounting and Economics 44 (1-2): 193-223.

Lawrence, A., Meza, M. M., \& Vyas, D. (2010). Relationship between internal control over financial reporting and internal control over operations: evidence from privacy breaches. Working Paper.

Peterson, B. K., \& Zikmund, P. E. (2004). 10 truths you need to know about fraud. Finance 10, May 2004.

Strategic

\section{RIWAYAT PENULIS}

Heny Kurniawati lahir di Temanggung dan menamatkan pendidikan DIV di Sekolah Tinggi Akuntansi Negara sedangkan pendidikan S2 ditempuh di University of Illinois at Urbana Champaign. Saat ini penulis adalah Faculty Member-Subject Content Coordinator di Universitas Bina Nusantara. 